\title{
Keragaman Gen Growth Hormone Receptor (GHR) Ekson 10 pada itik Sikumbang Janti
}

Polymorphism of Exon 10 Growth Hormone Receptor (GHR) gene in Sikumbang Janti Duck

\author{
H. Masti, Yurnalis*, T. D. Nova, Z. Kamsa, \& T. Rafian \\ Fakultas Peternakan, Universitas Andalas \\ Jl. Limau manis, Kec. Pauh, Kota Padang, Sumatera Barat 25157 \\ *Corresponding author: yurnalisunand@yahoo.com \\ (Received 07-11-2020; Revised 15-12-2020; Accepted 01-01-2021)
}

\begin{abstract}
Growth Hormone Receptor (GHR) gene play important roles in duck performances due to their crucial functions in growth and has been considered as a candidate gene for growth traits. This reasearch was aimed to indification polymorphism of Growth Hormon Receptor (GHR) gene in Sikumbang Janti duck and this study used 68 blood duck. Polymerase chain reaction (PCR) and sequencing analysis were conducted to detect SNP existence in exon 10 of GHR gene. The result of this study showed that was found two SNP at g.1112 A > G and g.1304 C > T with transision mutation in exon 10 GHR gene. Genotypes found in the g.1112 A>G were AA and GG with types of Allele A and G. Genotypes found in the g.1304 T $>C$ the were TT and CC with types of Allele $T$ and $C$. Polymorphism of GHR gene were polymorphic and Population of Sikumbang Janti duck in Hardy-Weinberg equilibrium. It could be concluded that GHR gene has potential to can be marker genetic in Sikumbang Janti ducks.
\end{abstract}

Keywords: GHR gene, variation, SNP, Sikumbang Janti duck

\begin{abstract}
ABSTRAK
Gen Growth Hormone Receptor (GHR) memainkan peranan penting dalam penampilan itik karena fungsinya yang sangat penting dalam pertumbuhan dan telah dianggap sebagai gen kandidat untuk sifat pertumbuhan. Penelitian ini bertujuan untuk mengidentifikasi polimorfisme gen Growth Hormon Receptor (GHR) pada itik Sikumbang Janti dengan menggunakan 68 ekor darah itik. Polymerase chain reaction (PCR) dan analisis sekuensing dilakukan untuk mendeteksi keberadaan SNP pada ekson 10 gen GHR. Hasil penelitian menunjukkan bahwa ditemukan dua SNP pada g.1112A $>$ G dan g.1304 T $>C$ dengan mutasi transisi di daerah ekson 10 gen GHR. Genotip yang ditemukan pada g.1112 A>G adalah AA dan GG dengan alel A dan G. Genotip yang ditemukan pada g.1304 T>C adalah TT dan CC dengan alel T dan C. Polimorfisme gen GHR bersifat polimorfik dan populasi itik Sikumbang Janti berada dalam keseimbangan Hardy-Weinberg. Dapat disimpulkan bahwa gen GHR berpotensi sebagai penanda genetik pada itik Sikumbang Janti.
\end{abstract}

Kata kunci: Gen GHR, keragaman, SNP, itik Sikumbang Janti

\section{PENDAHULUAN}

Itik Sikumbang Janti adalah salah satu itik lokal Sumatera Barat yang berasal dari daerah Payakumbuh khususnya kenagarian Koto Baru Payobasung. Itik Sikumbang Janti memiliki warna bulu putih keabu-abuan. Pada itik Sikumbang Janti jantan dewasa memiliki tanda abu-abu gelap pada bagian kepala, sedangkan pada itik Sikumbang Janti betina hanya putih polos dan ujung sayap berwarna cokelat keabu-abuan sehingga dapat dengan mudah dibedakan antara itik betina dan jantan (Nova et al. 2014). Warna paruh dan ceker itik Sikumbang Janti jantan dan betina yaitu cokelat tua (Nova et al. 2014). Itik Sikumbang Janti memiliki bobot badan 1.23-1.37 pada itik betina yang telah bertelur dengan produksi 190-210 butir/ ekor/tahun (Nova et al. 2014). Sehingga, Itik Sikumbang Janti memiliki potensi untuk dijadikan itik lokal yang produktif. 
Di sisi lain, keberadaan populasi itik Sikumbang Janti sering digantikan oleh itik lainnya. Hal ini dikarenakan peforma itik Sikumbang Janti lebih rendah dibandingkan dengan itik lainnya. Walaupun demikian itik Sikumbang Janti memiliki ketahanan terhadap cekaman panas (Subekti 2019). Hal ini menunjukkan itik Sikumbang Janti masih dapat dijadikan sebagai ternak itik potensial di Indonesia, dikarenakan Indonesia memiliki iklim tropis. Oleh sebab itu, perlunya meningkatkan peforma itik Sikumbang Janti. Salah satu caranya adalah menggunakan seleksi berbantuan marka. Penerapan seleksi berbantuan marka (MAS) memerlukan indikasi penciri gen kandidat.

Salah satu gen kandidat yang berperan dalam peforma yang bersifat ekonomis yaitu Gen Growth hormone Receptor atau GHR (Yurnalis dan Sarbaini 2014; Nova et al. 2016). GHR diduga mempengaruhi keragaman itik Sikumbang Janti. Gen GHR yang berperan dalam pertumbuhan preimplementasi (Izadyar et al. 2008) dan sel permukaan reseptor yang dibutuhkan oleh gen $\mathrm{GH}$ untuk membawa pengaruhnya ketarget jaringan (Moody et al. 1995). Mazurowski et al. (2014) menambahkan sifat peforma produksi merupakan sifat yang dipengaruhi banyak faktor dan gen, salah satunya adalah gen yang mempengaruhi pertumbuhan. Menururt Zhulkarnaim et al. (2010) faktor lain yang mempengaruhi pertumbuhan dari individu adalah gen GHR. Gen GHR terdiri dari 10 ekson dan 9 intron dan Gen GHR pada itik dipetakan sebagai gen tunggal yang terletak pada kromoson $\mathrm{Z}$.

Sampai saat ini belum dilakukan penelitian tentang keragaman Gen Growth Hormon Receptor (GHR) pada itik sikumbang janti, sehingga perlu dilakukan penelitian ini untuk mengetahui keragaman Gen Growth Hormon Receptor (GHR) pada itik sikumbang janti sebagai kandidat genetik yang berperan dalam pertumbuhan.

\section{MATERI DAN METODE}

\section{Sampel Penelitian}

Bahan penelitian ini adalah 68 sampel darah itik Sikumbang Janti dari Peternakan Unggul Utama Jaya Farm di Lubuk Minturung, Kota Padang.

\section{Sampel Darah}

Sampel darah diambil melalui vena achilaris menggunakan jarum suntik (Disposible Syringe $3 \mathrm{ml}$ ) sebanyak $\pm 2,5 \mathrm{ml}$, kemudian dimasukkan ke dalam tabung vacutainer EDTA dan disimpan pada suhu $-20{ }^{\circ} \mathrm{C}$ dari Peternakan Unggal Utama Jaya Farm di Lubuk Minturung, Kota Padang.

\section{Isolasi DNA}

Isolasi DNA dilakukan menggunakan prosedur Genomic DNA Purification Kit dari Promega. Sampel darah sebanyak $20 \mu \mathrm{l}$ dimasukkan ke dalam tabung eppendorf volume $2 \mathrm{ml}$ yang telah diisi larutan cell lysis solution sebanyak $200 \mu \mathrm{l}$, kemudian tabung dibolak balik sebanyak 4-6 kali untuk homogenesis. Sampel diinkubasi selama 10 menit pada suhu ruangan, sehingga proses pemecahan sel berjalan sempurna. Kemudian tabung dibolak balik kembali sebanyak 2-3 kali. Sampel disentrifugasi pada kecepatan 13000 rpm selama 20 detik. Hasil sentrifugasi akan menghasilkan endapan pada bagian dasar tabung. Kemudian larutan supernatant dibuang dan yang tertinggal dalam tabung hanya endapan untuk diproses lebih lanjut. Tabung eppendorf yang berisi endapan ditambahkan larutan nuclei lysis solution sebanyak $300 \mu \mathrm{l}$. Kemudian di mixdown dengan micropipet $1000 \mu$ l sampai cairan seluruhnya menjadi busa. Selanjutnya sampel diinkubasi selama 1 jam pada suhu $37^{\circ} \mathrm{C}$. Setelah diinkubasi sampel ditambahkan $100 \mu \mathrm{l}$ larutan protein preciptationi solution. Kemudian di vortex selama 10 detik. Selanjutnya disentrifugasi pada kecepatan 13000 rpm selama 3 menit. Supernatant hasil sentrifugasi dipindahkan ke dalam tabung eppendorf baru yang telah diisi $700 \mu \mathrm{l}$ isopropanol. Tabung yang berisi campuran dibolak balik sampai muncul benang-benang DNA. Setelah benangbenang DNA terlihat selanjutnya sampel disentrifugasi pada kecepatan $13000 \mathrm{rpm}$ selama 1 menit. Tabung hasil sentrifugasi yang berisi sampel DNA akan terlihat pellet putih dibagian dasarnya. Cairan supernatant dibuang dan tabung eppendorf berisi DNA ditambahkan larutan ethanol $70 \%$ sebanyak $700 \mu \mathrm{l}$. Tabung dibolak-balik secara perlahan untuk mencuci pellet, selanjutnya disentrifugasi pada kecepatan 13000 rpm 1 menit. Cairan ethanol 70\% dibuang kemudian tabung dibalikan diatas tisu steril dan di diamkan selama 20 menit. Setelah kering sampel DNA ditambahkan larutan DNA rehydration sebanyak $100 \mu \mathrm{l}$, kemudian typping tabung sehingga pellet larut atau diamkan sampel selama semalam pada suhu $4{ }^{\circ} \mathrm{C}$.

\section{Ampifikasi Gen GHR}

Amplifikasi menggunakan sepasang primer L: 5'AAA TCACAC AGC TGC TTG GG- ‘3 dan R: 5’-ACG GCA TGA TTT TGT TCA GCT-'3 yang dirancang menggunakan Primer3. Pereaksi amplifikasi PCR menggunakan Master mix (Thermo Scientific) dengan komposisi $2 \mu$ sampel DNA, $12.5 \mu \mathrm{l}$ Green Master Mix, $3 \mu \mathrm{l}$ campuran primer F dan R, dan $7.5 \mu \mathrm{l}$ Nuclease-Free Water.

Ampifikasi in vitro dilakukan dengan menggunakan mesin PCR (eppendorf® Mastercycler gradient) yang diprogram pradenaturasi pada temperatur $95{ }^{\circ} \mathrm{C}$ selama 5 menit, denaturasi pada temperatur $95{ }^{\circ} \mathrm{C}$ selama 45 detik, kemudian diannealing pada temperatur $61{ }^{\circ} \mathrm{C}$ selama 45 detik. Terakhir ekstensi $72{ }^{\circ} \mathrm{C}$ selama 1 menit. Siklus pradenaturasi hingga ekstensi diulang sebanyak 35 siklus, yang kemudian diakhiri dengan ekstesi terakhir (final extension) $72^{\circ} \mathrm{C}$ selama 5 menit.

Untuk melihat hasil amplifikasi gen GHR dielektroforesis menggunakan agarose $1,5 \%$ yang diwarnai dengan pewarnaan ethidium bromide dan hasilnya diamati dengan menggunakan UV transiluminator. Amplifikasi gen GHR dikatakan berhasil jika pada gel agarose terlihat pitapita pada posisi/ukuran pada sumur yang berisi sampel DNA produk PCR sesuai dengan target 793 yang dapat ditentukan dengan membandingkan posisi pita yang terbentuk dengan posisi pita DNA ladder. Kemudian hasil elektroforesis didokumentasikan dengan kamera

\section{Sekuensing Produk PCR}

Sekuensing dilakukan menggunakan jasa First Base Laboratory di Singapura untuk dianalisis direct sequencing 
menggunakan Dideoxy Sequencing ABI 3730 XL Automated DNA Sequencer.

\section{Analisis Data}

Hasil sekuensing fragmen gen GHR dianalisis menggunakan program Seqman versi 4.00 DNAStar. Selanjutnya, hasil sekuensing disejajarkan dengan hasil sekuens GenBank, kode akses Gen Bank: NC_040075

Frekuensi Genotipe. Hasil data genotip yang diperoleh dianalisis dalam bentuk frekuensi genotipe dihitung menggunakan rumus Nei dan Kumar (2000):

$$
x_{i i}=\frac{n_{i i}}{N}
$$

Keterangan :

$x i i=$ frekuensi genotipe ke-i

$n i i=$ jumlah individu bergenotip ii

$N=$ total jumlah individu sampel

Frekuensi Alel. Hasil data alel yang diperoleh dianalisis dalam bentuk frekuensi alel dihitung menggunakan rumus Nei dan Kumar (2000):

$$
x_{i}=\left(2 n_{i i}+\sum_{j \neq i} n_{i j}\right) / 2 n
$$

Keterangan :

$x i \quad=$ frekuensi alel ke-i

nii = jumlah individu yang bergenotip ii (homozigot)

$n i j \quad=$ jumlah individu yang bergenotip ij (heterozigot)

$n \quad=$ jumlah sampel

Keseimbangan Hardy-Weinberg. Penyimpangan frekuensi genotipe terhadap keseimbangan Hardy-Weinberg dianalisis menggunakan uji chi square $\left(\chi^{2}\right)$ berdasarkan rumus Nei dan Kumar (2000):

$$
\chi^{2}=\sum_{i=1}^{k} \frac{\left(o_{i}-e_{i}\right)^{2}}{e_{i}}
$$

Keterangan :

$$
\begin{array}{ll}
\chi^{2} & =\text { sebaran chi square } \\
o_{i} & =\text { frekuensi teramati ke-i } \\
e_{i} & =\text { frekuensi harapan ke-i }
\end{array}
$$

\section{HASIL DAN PEMBAHASAN}

\section{Deteksi Mutasi dan Keragaman Gen GHR Itik Sikumbang Janti}

Gen GHR disekuensing di First Base Laboratory di. Sekuen yang didapat kemudian dilakukan pensejajaran menggunakan program Seqman versi 4.00 DNA star berdasarkan data referensi Gene Bank (NC_040075), kemudian dilakukan analisis keragaman ditemukan beberapa single nucleotide polimorphism (SNP) pada itik sikumbang janti. Hasil ditemukannya beberapa mutasi pada Single Nucleotide Polimorphism (SNP) dapat dilihat pada Gambar 1 dan Gambar 2.

Identifikasi SNP dari hasil sekuensing gen GHR itik Sikumbang Janti menunjukkan terdapat dua SNP yang

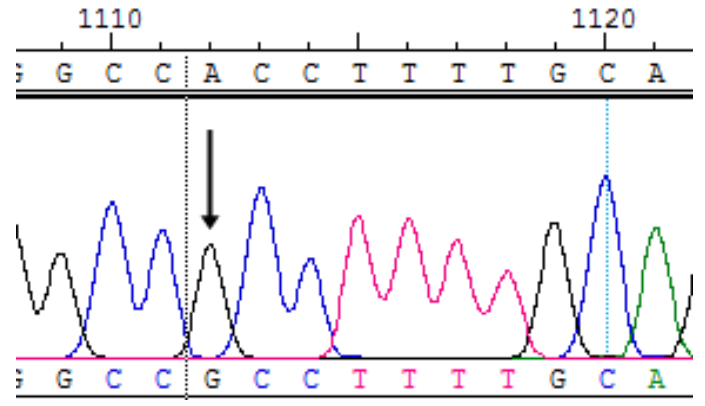

Gambar 1. SNP lokus $1112 \mathrm{~A}>\mathrm{G}$
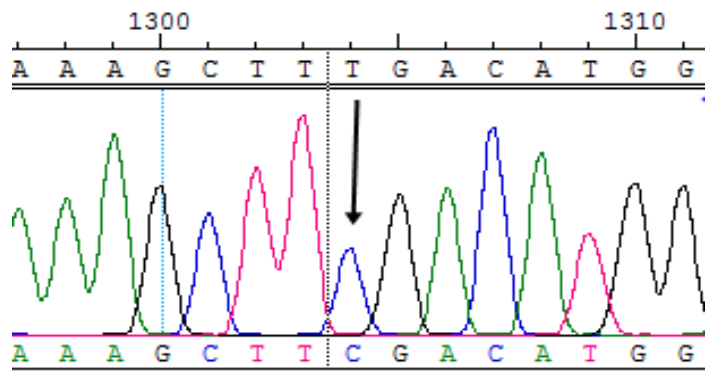

Gambar 2. SNP lokus $1304 \mathrm{~T}>\mathrm{C}$

mengalami perubahan nukleotida, yaitu g.1112 A>G dan g.1304 $\mathrm{T}>\mathrm{C}$, dan membentuk 1 haplotipe yang berbeda. Hal ini menunjukkan adanya keragaman pada gen GHR di populasi itik Sikumbang Janti. Pada penelitian sebelumnya oleh Khaerunnisa et al. (2016) menyatakan adanya keragaman pada gen GHR intron 5 pada ayam. Penelitian sebelumnya pada gen GHR ekson 10 belum ditemukan. Oleh karena itu, gen GHR pada itik Sikumbang Janti dapat dijadikan gen kadidat penanda genetik. Hal ini dikarenakan adanya keragaman gen GHR pada populasi itik Sikumbang Janti yang dapat dijadikan sebagai penanda. Huda et al. (2015) menambahkan gen GHR juga dapat digunakan sebagai penanda genetik yang informatif. Tabel hasil deteksi mutasi dan kergaman gen GHR ekson 10 dapat dilihat pada Tabel 1 dan 2.

Tabel 1. Deteksi Mutasi Gen GHR Ekson 10 itik Sikumbang Janti

\begin{tabular}{cc}
\hline Posisi & Tipe Mutasi \\
\hline g. $1112 \mathrm{~A}>\mathrm{G}$ & Transisi \\
g. $1304 \mathrm{~T}>\mathrm{C}$ & Transisi \\
\hline
\end{tabular}

Tabel 2. Keragaman Gen GHR Ekson 10 itik Sikumbang Janti

\begin{tabular}{ccc}
\hline Haplotipe & \multicolumn{2}{c}{ Lokus } \\
\cline { 2 - 3 } & 1112 & 1304 \\
\hline Ref & $\mathrm{A}$ & $\mathrm{T}$ \\
$\mathrm{A}$ & $\mathrm{G}$ & $\mathrm{C}$ \\
\hline
\end{tabular}

Frekuensi Genotip dan Frekuensi Alel SNP Gen GHR

Berdasarkan hasil analisis sekuen pada ekson 10 dari gen GHR itik Sikumbang Janti terdapat 2 SNP yang bermutasi. Menurut Arisuryanti dan Daryono (2007) 
Masti et al.

Jurnal Ilmu Produksi dan Teknologi Hasil Peternakan 9 (1): 15-19

Tabel 3. Frekuensi Genotip dan frekuensi Alel Gen GHR Ekson 10

\begin{tabular}{cccccccc}
\hline No & Posisi & $\mathrm{N}$ & \multicolumn{3}{c}{ Frekuensi genotip } & \multicolumn{2}{c}{ Frekuensi Alel } \\
\hline 1 & 1112 & 68 & AA & AG & GG & A & G \\
& $\mathrm{A} \rightarrow \mathrm{G}$ & & $0.85(58)$ & $0.00(0)$ & $0.15(10)$ & 0.85 & 0.15 \\
2 & 1304 & 68 & $\mathrm{TT}$ & $\mathrm{TC}$ & $\mathrm{CC}$ & $\mathrm{T}$ & $\mathrm{C}$ \\
& $\mathrm{T} \rightarrow \mathrm{C}$ & & $0.85(58)$ & $0.00(0)$ & $0.15(10)$ & 0.85 & 0.15 \\
\hline
\end{tabular}

Tabel 4. Hasil analisa keseimbangan Hardy-Weinberg gen GHR ekson 10 itik Sikumbang Janti

\begin{tabular}{|c|c|c|c|c|c|c|c|c|c|}
\hline \multirow{2}{*}{$\frac{\text { No }}{1}$} & \multirow{2}{*}{$\frac{\text { Posisi }}{1112}$} & \multirow{2}{*}{$\frac{N}{68}$} & \multicolumn{3}{|c|}{ Observasi } & \multicolumn{3}{|c|}{ Ekspetasi } & \multirow{2}{*}{$\frac{\text { Signifikan }}{\mathrm{Ns}}$} \\
\hline & & & GG & GA & $\mathrm{AA}$ & GG & GA & $\mathrm{AA}$ & \\
\hline & $\mathrm{A} \rightarrow \mathrm{G}$ & & 0.85 & 0 & 0.15 & 0.73 & 0 & 0 & \\
\hline \multirow[t]{2}{*}{2} & 1304 & 68 & $\mathrm{CC}$ & $\mathrm{CT}$ & TT & $\mathrm{CC}$ & $\mathrm{CT}$ & TT & Ns \\
\hline & $\mathrm{T} \rightarrow \mathrm{C}$ & & 0.85 & 0 & 0.15 & 0.73 & 0 & 0 & \\
\hline
\end{tabular}

Frekuensi gen pada suatu populasi dapat berubah jika ada evolutionary forces yaitu faktor- faktor yang berperan dalam mengubah frekuensi genotip dan alel yaitu mutasi, migrasi (gene flow), perkawinan tidak acak dan seleksi alam. Frekuensi alel bisa dilihat dari rasio relatif alel terhadap semua alel pada lokus yang berada di dalam populasi (Nei dan Kumar 2000).

Frekuensi genotipe gen GHR itik Sikumbang Janti pada posisi g.1112 $\mathrm{A}>\mathrm{G}$ dan g.1304 $\mathrm{T}>\mathrm{C}$ menunjukkan frekuensi genotip referensi (0.85) lebih tinggi dari pada nilai frekunesi genotip yang bermutasi (0.15). Hal ini menunjukkan gen GHR pada populasi itik Sikumbang Janti jarang terjadi mutasi. Hasil penelitian ini sama dengan penelitian Khaerunnisa et al. (2016) yang menyatakan mutasi pada gen GHR tidak banyak terjadi.

Frekuensi alel gen GHR itik Sikumbang Janti pada posisi g.1112 $\mathrm{A}>\mathrm{G}$ dan g.1304 $\mathrm{T}>\mathrm{C}$ menunjukkan frekuensi alel referensi (0.85) lebih besar dari frekuensi alel yang bermutasi $(0.15)$. Hal ini menunjukkan peluang terjadinya mutasi pada populasi itik Sikumbang Janti lebih kecil/besar. Hasil penelitian ini sama dengan penelitian Khaerunnisa et al. (2016) yang menyatakan peluang terjadinya mutasi pada gen GHR tidak banyak terjadi.

Berdasarkan hasil frekuensi penelitian dapat dikatakan keragaman Gen GHR itik Sikumbang Janti bersifat polimorfik. Hal ini sesuai dengan pernyataan Falconer dan Mackay (1996) yaitu suatu alel dikatakan polimorfik apabila memiliki frekuensi alel sama atau kurang dari 0.99. Selain itu menurut Nei (1987) keragaman genetik terjadi apabila terdapat dua alel atau lebih dalam populasi $<99 \%$. Frekuensi Genotip dan Frekuensi alel pada lokus gen GHR untuk masing-masing SNP disajikan pada Tabel 3.

\section{Keseimbangan Hardy-Weinberg}

Hasil analisa keseimbangan Hardy-Weinberg gen GHR ekson 10 pada itik Sikumbang Janti disajikan pada Tabel 4. Berdasarkan nilai keseimbangan Hardy-Weinberg, keragaman pada gen GHR ekson 10 pada populasi itik Sikumbang Janti berada pada keseimbangan HardyWeinberg. Hasil penelitian ini sama dengan penelitian Sumantri et al. (2010), yang menyatakan keragaman gen GHR berada dalam keseimbangan Hardy-Weinberg.
Hal ini menunjukkan mutasi pada populasi itik Sikumbang Janti terjadi secara natural tanpa adanya seleksi, migrasi, perkawinan di dalam populasi yang sama. Noor (2010), Mulliadi dan Arifin (2010) menyatakan populasi dalam keseimbangan Hardy-Weinberg menunjukkan tidak adanya mutasi seleksi, migrasi dan perkawinan di dalam populasi yang sama.

\section{KESIMPULAN}

Gen GHR pada itik Sikumbang Janti terdapat 2 SNP bersifat polimorfik dan keragaman gen GHR berpotensi sebagai penanda genetik pada itik Sikumbang Janti.

\section{UCAPAN TERIMAKASIH}

Penelitian ini dibiayai oleh Hibah DIPA Fakultas Peternakan Universitas Andalas tahun 2020.

\section{DAFTAR PUSTAKA}

Arisuryanti, T., \& B. S. Daryono. 2007. Genetika Populasi. Fakultas Biologi Universitas Gadjah Mada, Yogyakarta.

Falconer, D. S., \& T. F. C. Mackay. 1996. Introduction to Quantitive Genetics. $4^{\text {th }}$ Ed. Longman, New York.

Huda, N., M. Sriasih, \& Maskur. 2015. Identifikasi keragaman genetik gen growth hormon receptor dengan enzim retriksi MboII (GHR|MboII) pada sapi Bali. Jurnal Ilmu dan Teknologi Peternakan Indonesia. 1(1): 31-38.

Izadyar, F., H. T. Van tol, W. G. Hage, \& M. M. Bevers. 2000. Preimplantation bovine embryos express mRNA of growth hormone receptor and respond to growth hormon addition during in vitro development . Mol. Reprod. Dev. 74: 189-196.

Khaerunnisa, I., Jakaria, I. I. Arief, C. Budiman, \& C. Sumantri. 2016. The associattions of GH and GHR genes with carcass components in Indonesian Kampung and Broiler Chicken Cross. Med. Pet. 40(2): 78-87.

Mazurowski, A., A. Frieske, D. Kokoszynski, S. Mroczkowski, Z. Bernacki, \& A. Wilkanowska. 
2015. Examination of Growth Hormone (GH) gene polymorphism and its association with body weight and selected body dimension in ducks. Folia Biologica. 63(1).

Moody, D. E., D. Pomp, W. Barendse, \& J. E. Womack. 1995. Assignment of the growth hormone receptor gene to bovine chromosome 20 using linkage analysis and somatic cell mapping. Animal Genetic. 26:341-343.

Muliadi, D., \& J. Arifin. 2010. Pendugaan keseimbangan populasi dan heterozigositas menggunakan pola protein albumin darah pada populasi domba ekor tipis (Javanese Thin Tailed) di Daerah Indramayu. Jurnal Ilmu Ternak. 10(2): 65-72.

Nei, M., \& S. Kumar. 2000. Molecular Evolution and Phylogenetics. New York (United State): Oxford University Press, Inc.

Nei, M. 1987. Molecular Evolutionery Genetics. New York. Columbia University Press.

Noor, R. R. \& K. B. Seminar. 2009. Rahasia dan Hikmah Pewarisan Sifat. IPB press, Indonesia.

Nova, T. D., F. Arlina, \& Fricillya. 2014. Karakteristik fenotipe Itik Sikumbang Janti sebagai itik lokal Payakumbuh. Hlm. 525-31 dalam Prosiding Seminar Nasional Teknologi Peternakan dan Veteriner.
Nova, T. D., Yurnalis, \& A. K. Sari. 2016. Keragaman genetik gen hormon pertumbuhan (GH|Mboll) pada itik Sikumbang Janti menggunakan penciri PCR-RFLP. Jurnal Peternakan Indonesia. 18(1): 44-52.

Subekti, K., D. D. Solihin, R. Afnan, A. Gunawan, \& C. Sumantri. 2019. Polymorphism of duck HSP70 gene and mRNA express under heat stress conditions. Int. J. Poult. Sci.18(12): 591-597.

Sumantri, C., R. Diyono, A. Farajalah, A. Anggraeni \& E.Andreas. 2010. Pemanfaatan famili gen hormon pertumbuhan (GH, GHR, GHRH, dan PIT-1) untuk mendeteksi keragaman genetik kerbau di Kabupaten Pandeglang dan Lebak Provinsi Banten. Jurnal Ilmu Ternak Dan Veteriner. 15(4): 286-296.

Yurnalis, \& Sarbaini. 2014. Keragaman sekuen gen reseptor hormon pertumbuhan exon 10 sebagai informasi dasar seleksi pada sapi Pesisir plasma nuftah Sumatera Barat. Jurnal Peternakan Indonesia.16(1): 63-70.

Zulkharnaim., Jakaria, \& R. R. Noor. 2010. Identifikasi keragaman genetik gen reseptor hormon pertumbuhan (GHR $\mid$ Alu I) pada sapi Bali. Med. Pet. 33(2): 81-87. 